\title{
A gyermekvállalási és családtámogatási rendszer egyes állampénzügyi szegmensei Szlovákiában
}

\author{
Lentner Csaba \\ Nemzeti Közszolgálati Egyetem \\ Károli Gáspár Református Egyetem \\ lentner.csaba@uni-nke.hu \\ Horbulák Zsolt \\ Pozsonyi Közgazdaságtudományi Egyetem \\ zsolt.horbulak@euba.sk
}

\begin{abstract}
Összefoglaló
A gyermekvállalási hajlandóság csökkenésének problémájával a világ számos országa küzd. Tanulmányunkban Szlovákia demográfiai viszonyait elemezzük történelmi léptékben, majd bemutatjuk azokat az adópolitikai és támogatási eszközöket, amelyekkel a szlovák kormány a gyermekvállalást és a nevelést kívánja elősegíteni. Jelen tanulmány témaválasztása tulajdonképpen egy közvetett kísérlet a magyar népesedési és népesedéspolitikai intézkedések megítélésének igazolására. Korábbi kutatásainkban, empirikus vizsgálatokkal alátámasztva arra jutottunk, hogy Magyarország és Szlovákia hasonló fejlettségű és számos szempontból hasonló adottságú ország, amelyek a 2010-es évek eleje óta széles körű adópolitikai és lakásépítési támogatásokat biztosítanak. Azt elemeztük, hogy a szülőképes korú nők, családok ezekhez a támogatásokhoz hogyan viszonyulnak, valamint emelkedik-e a támogatások hatására a gyermekvállalási hajlandóság. Kifejtettük, hogy a magyar fiatalok körében kedvező a kormány CSOK-rendszere és adókedvezményei fogadtatása, ám a gyermekvállalási hajlandóság előmozdítása az állampénzügyi kedvezményeken és támogatásokon túl számos körülménytől függ. A szlovákiai viszonyok elemzésével a magyar rendszer esetleges továbbfejlesztésére, a családvállalás szempontjainak más aspektusaira is fel kívánjuk hívni a figyelmet.
\end{abstract}

KulcsszavaK: családi adókedvezmények, otthonteremtés, demográfia, Szlovákia, Magyarország JEL-KóDoк: I38, J13, R21

DOI: https://doi.org/10.35551/PSZ_2021_4_2 
A gyermekvállalási hajlandóság a világ fejlett országaiban romló tendenciát mutat, s ennek ellensúlyozására rendre megjelennek azok az állampénzügyi eszközök (jobbára adókedvezmények és támogatások formájában), amelyekkel a kormányok változtatni szeretnének a születésszám egyre aggasztóbb alakulásán.

\section{A KUTATÁS ELMÉLETI ÉS LOGIKAI HÁTTERE}

Az európai országokban is romlik a termékenységi ráta, ezáltal a népesség csökken (Beaujouan et al., 2017; Dorbritz, 2018, 4546; Neyer et al., 2016,1), noha a gyermekvállalási kedv élénkülése elősegíthetné a népességszám növekedését (Sobotka, 2011), amivel a térség gazdasági aktivitása erősödhetne.

Lényeges, hogy a gyermekvállalásról szóló döntés az egyénnél összpontosul, ám a kormányzati döntések és intézkedések hatása (is) kimutatható (Liefbroer et al., 2015). A gyermekvállalást javító beavatkozások a gyermeknevelés relatív költségeire hatnak, s jobbára a foglalkoztatásban való részvételt, a család megélhetését, lakhatás megoldását vagy a szülők újra munkába állását segítik (Neyer, 2006; Stefán-Makay, 2009; Lieber Luci-Greulich, Thévenon, 2013). Kérdésfeltevésünk Sorvachev és Yakovlev (2019) alapján, hogy a lakhatási és más támogatások legalább részben ellensúlyozzák-e a gyermekvállalással járó többletterheket (és haszonáldozatot), vagyis egy Magyarországhoz hasonló fejlettségü és kultúrájú országban a családpolitika milyen jellemzőkkel bír? A kormányzati támogatások meghatározók a gyermekvállalásban.

A tanulmány a szlovák viszonyok bemutatásával párhuzamot kíván állítani a már számos szakmai fórumot megjárt, magyar viszonyokat elemző kutatási eredményeinkkel. Arra keressük a választ, hogy a szlovák népesedési adatok miért kedvezőbbek, mint a ma- gyar adatok, noha Magyarország társadalompolitikáját 2010-től a demográfiai kérdések előtérbe kerülése jellemzi, amelynek kettős célja van. Egyrészt elősegíteni a vágyott számú gyermek megszületését, s ezzel megállítani a négy évtizede tartó népességszám csökkenését, másrészt támogatni a további gyermekvállalást (Novák, 2020), mert végső soron az országok jövőjét a demográfia határozza meg (Singhammer, 2019). Magyarország kormánya - a 2010-től elindított családi adókedvezményeket fenntartva - 2012-től otthonteremtési programot indított, amelyet 2015-ben kiszélesítettek, majd a támogatások feltételei tovább bővülnek - mondhatni folyamatosan. ${ }^{1}$ 2017-ben empirikus kutatás keretében megvizsgáltuk, hogy a gyerekvállalási korba érő fiatalok szándékait előreláthatóan megváltoztatja-e a támogatási rendszer megléte. Saját kérdőíves vizsgálatunkban 1332 felsőoktatásban tanuló hallgató vett részt. A válaszadók 73,4 százaléka szerint a gyerekvállalási kedvet növeli az otthonteremtési támogatás, azonban csak a 36,7 százalék válaszolta azt, hogy a támogatási rendszer fennmaradása esetén maga is vállalna több gyereket. Megállapítottuk, hogy az otthonteremtési támogatás pozitívan befolyásolja a gyerekvállalási kedvet (Tatay et. al., 2017). A 2018-ban elvégzett kutatásunk (Sági, Lentner, 2018) a magyar felsőoktatásban tanulók (potenciális családalapítók) már több mint 9 százalékára, az előző minta, több mint tízszeresére, 15700 före terjedt ki. Értékelhető válaszaik, a korábbi (2017-es), kisebb mintavételtől eltérő szignifikáns véleményt nem tükröznek. A vizsgálat rámutatott arra is, hogy a családoknak juttatott lakástámogatások a lakásárakra jelentős felhajtó hatást gyakorolnak, aminek következtében, föleg nagyobb, munkahelyekkel jobban ellátott városokban a lakáshoz jutás anyagi feltételei lényegesen nem javulnak. Javaslatként került megfogalmazásra, hogy a kormány ne csak a családok lakáskeresleti viszonyait szabályozza, 
hanem az építési piacon is szabályozóként és kivitelezőként lépjen fel.

Elemzéseink a nemzetközi kutatási eredményeket is figyelembe vették. Baughman és Dickert-Conlin (2007) az adórendszerben bevezetett hirtelen nagymértékű jövedelemkedvezményeknek a születésszámokra gyakorolt hatását vizsgálták az Egyesült Államokban, az 1990 és 1999 közötti időszakra. Kiindulási pontjuk, hogy a jövedelemadók olyan exogén változót képviselnek, amely a gyermekvállalás és gyermeknevelés költségein keresztül a gyermekvállalási döntéseket is befolyásolja (lásd például Whittington, 1992). A várttal ellentétben a szerzők azt találták, hogy az adókedvezmények kiterjesztése nemhogy nem növelte, hanem csökkentette a születésszámot. Hasonló negatív, vagy legalábbis nem a várt hatású korreláció figyelhető meg a lakásépítési direkt támogatásoknál is. Saját kutatási eredményeink azt is jelzik, hogy a lakhatási támogatások összege nem elég magas ahhoz, hogy ösztönözze a gyermekvállalást, tekintettel arra, hogy ezek a fiatal felnőttek a fejlettebb nagyobb városokban fognak munkát és lakóhelyet keresni, ahol a lakások egyre drágábbak. Rövid távra elöre tekintve Riederer és BuberEnnser (2016) tanulmánya megerősíti azt a következtetésünket, hogy bár a gyermekvállalási hajlandóság hasonló a nagyvárosokban és a vidéken élő fiatalok esetében, azonban ténylegesen a gyermekvállalás valószínűsége kisebb a nagyvárosban élőknél.

A magyar közgazdasági gondolkodásban más kutatóknál is - felerősödtek a gyermekvállalás gazdaságpolitikai eszközökkel történő segítésére irányuló javaslatok, amelyek közül van olyan kutató (Giday, 2012), akik az életciklus-szemlélettel, mások (Banyár, 2020; Botos, 2019) a családvállalás „áldozatait” a nyugdíjrendszerben történő kései kompenzálással kívánják elősegíteni. Ám van olyan kutató is, aki arra a következtetésre jut, hogy a népességfogyás és az elöregedés nemzeti keretek kö- zött nem szüntethető meg, sőt számottevően nem is enyhíthető, akármilyen nagy pénzöszszeggel is próbálja az állam csökkenteni a gyermekvállalás egyéni költségeit (Mihályi, 2019), amelyet jelen tanulmány szerzői nem feltétlenül osztanak.

Tény ugyanakkor, hogy a Covid-19járványválság ellenére is a magyar családtámogatások töretlen lendületűek, ám a legfrissebb születési adatok csak szerényen mutatnak az állami támogatásokhoz „idomuló” születésszám-többletet. 1998-tól az élve születések száma 100 ezer alatt van (inkább a 90 ezerhez közelebb) folyamatosan, amit az elmúlt 22 évben nem sikerült érdemben javítani. ${ }^{2}$ Ám lényeges, hogy az ezer lakosra jutó születésszám az új kormány adó-, majd építéstámogatási kedvezményei hatására a 2010-es kormányváltási évben tapasztalt 9-es arányról 2020-ra 9,5-re emelkedett, míg a teljes termékenységi arányszám is 1,25-ról 1,56-ra javult.

2021 első öt hónapjában Magyarországon 36375 gyermek jött világra, ami 231 újszülöttel (0,6 százalékkal) kevesebb a 2020. január-májusi születésszámnál. Ezen belül januárban 9,4, április-májusban 2,0 százalékkal kevesebb, míg februárban 1,4, márciusban 10 százalékkal több volt az élve születések száma 2020 azonos hónapjaihoz képest. A teljes termékenységi arányszám 1 nőre számított becsült értéke 1,50 volt a 2020. január-májusra számított 1,48-hoz képest. Mindezen magyar adatok indokolják annak mélyebb vizsgálatát, hogy egy hasonló fejlettségü, „szomszéd” országban, ha minimálisan is, de miért jobbak az adatok. ${ }^{3}$

\section{A TANULMÁNY MÓDSZERTANI MEGFONTOLÁSA}

A kedvezőtlen magyar demográfiai adatokat egy hasonló történelmi múlttal, hasonló gazdasági fejlettségi szinttel és fejlődési dinami- 
kával rendelkező szomszédos ország adataival vetettük össze (lásd a 2. táblázat alapján). Az 1. táblázatban látható, hogy az uniós átlagot leginkább Csehország közelítette meg. Magyarországhoz képest Szlovákia pozíciója - bár némileg jobb, de - igen nagy mértékü hasonlóságot mutat.

Kutatásunkban feltételezzük, hogy Szlovákia demográfiai mutatói kedvezőbbek, ám ennek a hátterében zajló adópolitikai kedvezmények és lakásberuházási támogatások vonatkozásában a magyartól eltérő szignifikáns különbséget nem vélelmezünk, vagyis a magyar gyakorlatnál és mértéknél nem erősebbek. Vagyis a gazdasági fejlettség, a társadalmi viszonyok hasonlóak, földrajzi közelség adott, ám kérdéses, hogy a családpolitika fejlesztésébe befektetett állampénzügyi támogatások és fiskális kedvezmények milyen hatást váltanak ki az élve születések alakulásában. Hipotézisünk, hogy az állami támogatások, illetve az állami támogatások fajlagos erőssége a magyar oldalon nem gyakorol lökésszerü pozitív felhúzó hatást a gyermekszületésre, vagyis nem az állami támogatásokon múlik a gyermekvállalás. Mindezek igazolásához Szlovákia történelmi dimenziókba ágyazott főbb gazdasági és társadalmi adatait vizsgáljuk meg, bemutatva a szlovák családtámogatási rendszer múltját és jelenét.

1. táblázat

\section{AZ EGY FÕRE JUTÓ GDP VÁSÁRLÓERŌ-PARITÁSON, AZ EU-28 SZÁZALÉKÁBAN}

\begin{tabular}{|l|c|c|}
\hline & $\mathbf{2 0 1 0}$ & $\mathbf{2 0 1 9}$ \\
\hline Magyarország & 65,1 & 72,7 \\
\hline Szlovákia & 69,7 & 75,0 \\
\hline Csehország & 83,3 & 92,2 \\
\hline
\end{tabular}

Forrás: Eurostat

2. táblázat

\section{ÉLVE SZÜLETÉSEK ÉS TERMÉSZETES SZAPORODÁS CSEHSZLOVÁKIÁBAN [1000 FÖ́RE]}

\begin{tabular}{|c|c|c|c|c|c|c|}
\hline \multirow{2}{*}{ Év } & \multicolumn{3}{|c|}{ Élve szîletettek } & \multicolumn{3}{|c|}{ Természetes szaporodás } \\
\hline & Csehszlovákia & Csehország & Szlovákia & Gsehszlovákia & Csehország & Szlovákia \\
\hline 1937 & 16,3 & 14,3 & 22,6 & 3,2 & 1,5 & 8,6 \\
\hline 1947 & 24,2 & 23,6 & 25,8 & 12,1 & 11,6 & 13,6 \\
\hline 1962 & 15,7 & 13,9 & 19,8 & 5,7 & 3,1 & 11,7 \\
\hline 1968 & 14,9 & 13,9 & 17,0 & 4,2 & 2,2 & 8,5 \\
\hline 1974 & 19,9 & 19,4 & 20,8 & 8,2 & 6,7 & 11,2 \\
\hline 1989 & 13,3 & 12,4 & 15,1 & 1,7 & 0,1 & 5,0 \\
\hline 1992 & 12,6 & 11,8 & 14,1 & 1,4 & 0,1 & 4,0 \\
\hline
\end{tabular}

Forrás: Průcha et al., 2009, 902. oldal 


\section{TÖRTÉNELMI VISSZATEKINTÉS: CSEHSZLOVÁKIA DEMOGRÁFIAI VISZONYAI}

1918 végén két jelentősen eltérő ország Csehország és Szlovákia - egyesült és hozott létre egy közös államot. Annak ellenére, hogy a két fó államalkotó nemzetet a nagyon hasonló nyelv összekötötte, az országrészek között jelentős különbségek voltak, amelyek magukba foglaltak kulturális, politikai, társadalmi, vallási, gazdasági és demográfiai eltéréseket is. Csehország polgárosodottabb és városiasodottabb volt (Zemko, Bystrický, 2004), s a felbomló Monarchia egyik legiparosodottabb vidékei közé tartozott. Szlovákia ezzel szemben elmaradottabb régió volt, annak ellenére, hogy a történelmi Magyarország részeként annak fejlettebb vidékei közé tartozott. Csehországgal szemben az ország fennállása idején folyamatosan alárendelt szerepben maradt. A gazdasági elmaradottságot a két háború között a cseh központosító gazdaságpolitika inkább tovább mélyítette. A szlovákiai ipar a cseh ipar árnyékában nem fejlődött eléggé, sőt, esetenként leépült (Habaj et al., 2015), aminek negatív társadalmi következményei is voltak. 1945 után aztán a helyzet változott, noha politikai egyenrangúságot csak az 1968-as prágai tavasz eredményeképp tudott kiharcolni. A szocializmus négy évtizede alatt a szlovák országrész mérsékelten fel tudott zárkózni a cseh színvonalhoz. Amíg 1948-ban a szlovák országrészben a Csehszlovákiában megtermelt nemzeti jövedelem 19,2 százalékát állították elő, 1990-ben már 30,9 százalékát. A bruttó ipari termelés esetében ezek a számok 13,5 illetve 30 százalék, a bruttó mezőgazdasági termelés esetén 29,3 és 32,3 százalék volt, a magánfogyasztás pedig 23,9 százalékról 31,8 százalékra emelkedett (Průcha V. et al., 2009).

A leírtak a népmozgalmi adatokban is megmutatkoztak. A népszaporulat a nyugati or- szágrészben Csehszlovákia fennállása idején folyamatosan alacsonyabb maradt. Konstatálható, hogy a gyermekvállalási hajlandóság a gazdasági fejlettséggel fordított arányban változott, amelyet az 2. táblázat igazol.

Szlovákia lakosságának az aránya, egyben a szlovák nemzet aránya is, a háromnegyed évszázad alatt emelkedett. Amíg az első hivatalos cenzus idején 1921-ben, a lakosság 15,13 százaléka vallotta magát szlováknak, arányuk 1991-re 31,04 százalékra nőtt. Igaz a csehek részaránya is nőtt 52,52 százalékról 54,03 százalékra. Ez a növekedés azért volt lehetséges, mivel több mint hárommilliós németség a második világháború után szinte teljesen eltűnt az országból, és a többi nemzetiség részaránya, így a magyarságé is csökkent (Gyurgyík, 1994).

Szlovákia lakosságának, illetve a szlovák etnikum növekedése annak ellenére történt, hogy az ország keleti részéből folyamatosan áramlott a munkaerő az ország nyugati felébe. A folyamat a második világháború után gyorsult fel. A Szudéta-vidékről kitelepített németek helyébe jobbára szlovák telepesek érkeztek, majd a gyorsuló iparosítás szintén sok szlovákot csábított át Csehországba.

Csehszlovákia történetében három baby boom időszak volt (lásd az 1. ábrán). Az első és második születési hullám, akárcsak a világ nagyon sok országában, a két világháború után ment végbe. A harmadik hullámra az 1970-es és 1980-as években került sor. Ez a demográfiai mozgás nem egyedi jelenség, hiszen a második baby boom generáció képviselői máshol is ekkor kerültek szülőképes korba, viszont Csehszlovákia esetében voltak bizonyos specifikumok. A kérdést bővebben a következő részben tárgyaljuk.

A demográfiai adatokat tekintve a szlovák országrészen belül is lényeges különbségek voltak. Szlovákia keleti és észak-keleti vidékein a sokgyerekes családmodell továbbra is fennmaradt, az ország nyugati felén azonban az urbanizációnak, a főváros elhelyezkedésének, továbbá 


\section{TERMÉSZTES SZAPORODÁS ALAKULÁSA CSEHSZLOVÁKIÁBAN}

[\%o]

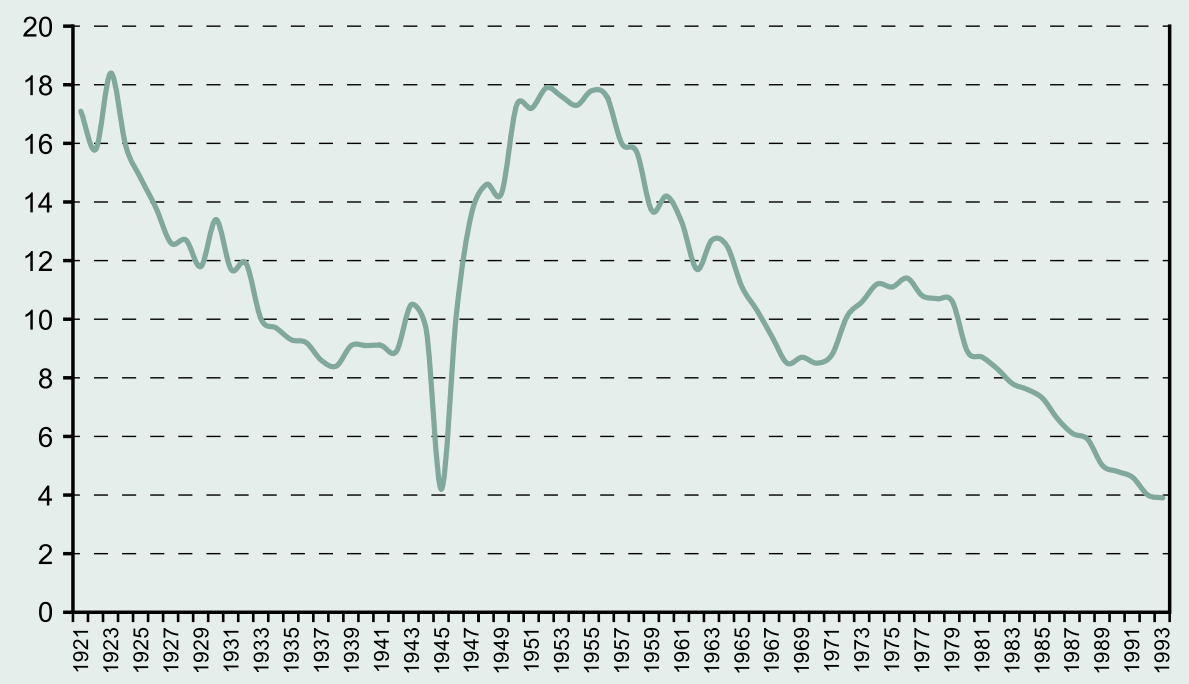

Forrás: Štatistická ročenka Slovenskej republiky, 2017, 63-65. oldal

a belső vándorlásnak köszönhetően a lakosság szintén gyarapodott, ellenben a születések száma alacsonyabb volt. Az 1950-es évektől az is megfigyelhető volt, hogy a déli járásokban a lakosság növekedése elmaradt az ország lakosságának növekedési ütemétől (Gajdoš, Pašiak, 2006). Ezeknek a járásoknak a negatív demográfiai helyzete alapvetően a magyarság negatív népesedési mutatóiban keresendő: lásd 3. táblázat alapján.

A magyar nemzetiségű lakosság kedvezőtlen népesedési viszonyai között - sok más tényező mellett - meghúzódhat a fiatalabbak elvándorlása iparosodott országrészekbe, másrészt az is, hogy jobbára csak az idősebbek vallják magukat magyarnak.

A fejezet alapján megállapítható, hogy Csehország és Szlovákia eltérő népesedési adatai, illetve gyermekvállalást meghatározó eltérő tényezői között szerepet játszik a keresztényi kultúra, a hagyomány, de akár a gazdasági fej- lődés viszonylagos alakulása is, Szlovákián belül pedig a jelentősebb roma lakosság által gazdagított etnikai háttér.

\section{A SZOCIALISTA CSEHSZLOVÁKIA SZOCIÁLPOLITIKÁJA}

A prágai tavasz bukása után Csehszlovákia Kommunista Pártja a hatalmát szociálpolitikai intézkedések sorával kívánta stabilizálni. Erre Csehszlovákiának reális lehetőségei voltak, mivel az ország a keleti blokkon belül az egyik legerősebb gazdasággal rendelkezett és a lakossága az egyik legjobb ellátást élvezte. A népesedési többlet megjelenése természetesen a gazdaságra is ösztönzőleg hatott. A kor szociálpolitikájának egyik máig leglátványosabb eredménye volt a gyermekvállalást előmozdító panelházak megépítése, amely szinte mindegyik városi rangú település részévé vált. 


\section{TERMÉSZETES NÉPSZAPORULAT SZLOVÁKIÁBAN [\%]}

\begin{tabular}{l|c|c|c|c|c|c|c|}
\hline & $\mathbf{1 9 5 5 - 5 9}$ & $\mathbf{1 9 6 0 - 6 4}$ & $\mathbf{1 9 6 5 - 6 9}$ & $\mathbf{1 9 7 0 - 7 4}$ & $\mathbf{1 9 7 5 - 7 9}$ & $\mathbf{1 9 8 0 - 8 4}$ & $\mathbf{1 9 8 5 - 8 9}$ \\
\hline Országos & 16,13 & $\mathbf{1 2 , 8 6}$ & $\mathbf{9 , 5 8}$ & 9,86 & 10,91 & 8,27 & 6,16 \\
\hline Magyarság & 13,41 & 8,14 & 5,54 & 5,24 & 6,01 & 4,64 & 3,36 \\
\hline
\end{tabular}

Forrás: Gyurgyík, 1994, 129. és 133. oldal

Az 1969 tavaszán meghozott rendelkezéseket a szakirodalom stabilizációs intézkedéseknek nevezi. Ezek többek között ármoratóriumot, meghatározott bérnövekedést, illetve elbocsátási szigorításokat tartalmaztak. Létrehozták az Állami Népesedési Bizottságot. Az anyasági szabadság hosszát 26 hétre emelték. Később megkezdték az anyasági hozzájárulás kifizetését, aminek az összegét egy éven belül megduplázták. 1973-tól a családtámogatás összegét a gyermekek számától tették függővé, majd bevezették a fiatal családok hiteltámogatását. A családok segítésében a vállalatoknak és a szakszervezetnek is szerepet kellett vállalniuk. A természetbeni juttatások közé tartozott a teljesen ingyenes iskoláztatás, étkezési és utazási kedvezmények, dotált lakbér, továbbá az ártámogatott gyermekruhák (Průcha et al., 2009). Az intézkedések megmutatkoztak a születésszám növekedésén is. A demográfiai csúcs eléréséhez hozzájárult a korábbi népbetegségek visszaszorítása és a csecsemőhalandóság jelentős csökkentése is. Ebben a két évtizedben született csecsemőket a szakirodalom husáki gyerekeknek nevezi. ${ }^{4}$

A szocialista rendszer negatív velejárói azonban Csehszlovákia esetében is megmutatkoztak. Az egyre gyengébb gazdaság nehezebben volt képes fenntartani a szociális rendszert. Ami az ország külső eladósodását illeti, a szocialista Csehszlovákia esetében a kép vegyes volt. Csehszlovákia a fejlődő világ (szocialista orientációjú) országaival szemben jelentős hitelezői pozícióban volt, és a tőkés országokkal szem- ben is folyamatosan emelkedtek az adósságai. A bruttó eladósodás 1981-ben volt a legmagasabb. Ennek mértékét az adott korszakban nem hozták nyilvánosságra. Tény azonban az, hogy Csehszlovákia a legkevésbé eladósodott szocialista országok közé tartozott. 1970-ben 909,8 millió dollár tartozása volt az országnak, ami 1975-re 1 880,8 millióra, 1980-ra pedig 7 763,3 millióra nőtt. 1985-ra kisebb esés következett - 5 574,1 millió dollár, majd 1989-re ez 8691 millió dollárra nőtt (Průcha V. et al., 2009). A hiteltörlesztés a lakosság ellátásában alig okozott nehézséget (a tervgazdasági rendszer végére bruttó 21,3 milliárd dollárra emelkedő magyarhoz képest), egyben hozzájárult ahhoz, hogy a rendszerváltás után könnyebben kezdhesse meg a piacgazdaság kiépítését.

\section{A JELENLEGI CSALÁDPOLITKAI HÁTTÉRRÓL: SZLOVÁKIA GAZDASÁGI HELYZETÉNEK VÁZLATA}

Ahogy azt a volt Csehszlovákiában végbemenő rendszerváltozást megnevező kifejezés is mutatja - bársonyos forradalom - Magyarország északi szomszédjában a szocializmusból a demokratikus rendszerbe történő átmenet gyors volt és erőszakmentes (Jašek et al., 2019). A politikai változások a lakosságot gyakorlatilag váratlanul érték. A piacgazdaságban meglévő negatív jelenségek is sokkszerűen jelentek meg. A fogyasztói árak 1990-ben még csak 10,6 százalék, a következő évben azonban már 
61,2, 1992-ben 10,0, 1993-ban 23,2, 1994 ben pedig 13,4 százalékkal nőttek. Ebből kifolyólag a reálbérek is gyorsan estek, majd nagyon lassan zárkóztak fel. 1989-hez a képest az 1991 és 1994 közötti intervallumban a következőképpen változtak: 70,4; 76,6; 72,5; 73,9 (Statisztikai Évkönyv, 1995; 118, 170). Ehhez, illetve az ehhez kapcsolódó jelenségek (például munkanélküliség stb.) folyományaként az 1990-es évtized első felében a születési szám 79 989-ről 66 370-re esett, azaz 17 százalékkal kevesebb gyerek jött a világra.

Szlovákia társadalmi, politikai és gazdasági fejlődését nehezítette, hogy a valódi rendszerváltozás folyamata elhúzódott. A belpolitikai okok miatt (Leško, 1998) a szociális piacgazdaság kiépítése lelassult, és az ország nem csatlakozott a V4-országokkal együtt a NATO-hoz. A belpolitika Szlovákiában az ezredforduló éveiben aztán jelentős irányváltozáson ment keresztül mind politikai, mind pedig gazdasági értelemben. 1998-ban egy nyugatorientált kormánykoalíció került hatalomra, amely az új évezred első éveiben több átfogó reformot hajtottak végre (Mikloš, 2005), aminek eredményeképpen gyors gazdasági növekedés indult meg. Szlovákia gazdasága a 2000-es évek folyamán kiemelkedően teljesített. A jó makrogazdasági mutatók ellenére Szlovákia mégis sokáig elmaradt az uniós tagországoktól, egyben a szomszédos országoktól, a munkanélküliség aránya Szlovákiában sokáig magas volt, és csak a 2010-es évek végén kezdett érdemben csökkeni (Nagy, 2016).

Egyrészt a csehszlovák örökségként, másrészt a jó makrogazdasági helyzetnek köszönhetően Szlovákia eladósodottsági rátája alacsonynak volt mondható, különösen Ma-

\section{SZLOVÁKIA ÉS MAGYARORSZÁG BRUTTÓ ELADÓSODOTTSÁGA A GDP SZÁZALÉKÁBAN}

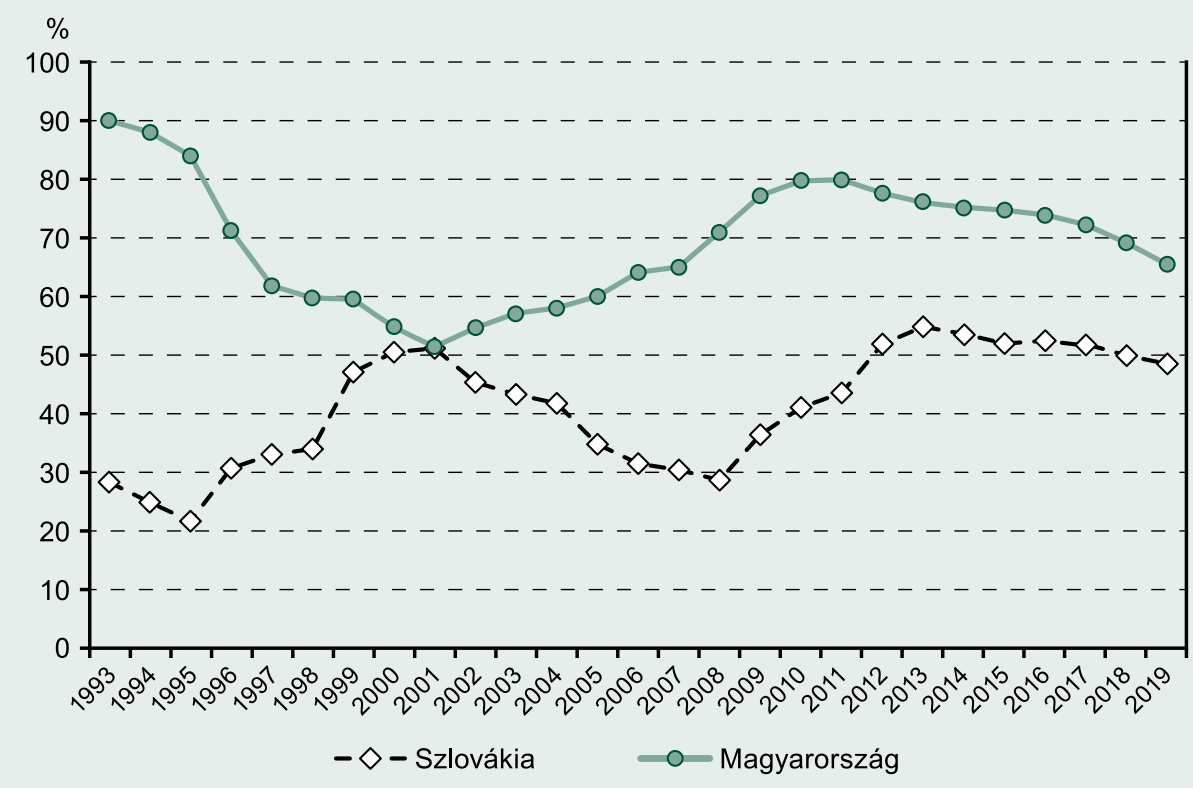

Forrás: www.mfsr.sk; www.ksh.hu 
gyarországhoz képest (2. ábra). Ez nagyban hozzájárult ahhoz, hogy kevesebbet kellett adósságszolgálatra költenie, és anyagi forrásait más célra használhatta fel.

\section{A DEMOGRÁFIAI HELYZET VÁLTOZÁSA SZLOVÁKIÁBAN A RENDSZERVÁLTOZÁS UTAN}

A rendszerváltozást kísérő társadalmi megrázkódtatások ellenére Szlovákia demográfiai helyzete nem tekinthető rossznak. Ahogy a 3. és 4. ábra mutatja, a népesség száma nem csökken, hanem lassan növekszik. Mindez annak ellenére történik, amint arra korábban utaltunk, hogy a rendszerváltozás után a születések száma gyorsan visszaesett, és az Európai Unióhoz való csatlakozás idején jelentős számú szlo- vák állampolgár költözött hosszabb-rövidebb időre európai uniós tagállamba. Ez a migrációs hullám sem hozott jelentős demográfia veszteséget, mivel a népességveszteség 2013 és 2019 közötti időszakban évente mintegy 5 és 7 ezer föt jelentett (Eurostat).

Az említett gazdasági és társadalmi változások folyományaként a bruttó születési ráta az 1990-es években gyorsan csökkenésnek indult, és 2000-re az uniós átlag alá esett. Ez az állapot azonban nem tartott sokáig, a fordulat éve 2008-ban történt, és a születési többlet máig fennmaradt. Szlovákia ezen demográfiai mutatója bizonyos mértékben hasonlítható a csehországi számokhoz. A cseh születési ráta gyakorlatilag évtizedek óta elmaradt a szlováktól, de a tendenciák ennek ellenére továbbra is hasonlók, sőt, az olló 2002-ben szinte összezárt, és 2009-től meghaladta az uniós átlagot. Szlo-

\section{A SZÜLETÉSI RÁTA ALAKULÁSA CSEHORSZÁGBAN, MAGYARORSZÁGON, SZLOVÁKIÁBAN ÉS AZ EURÓPAI UNIÓBAN [SZÜLETÉSEK SZÁMA 1000 LAKOSRA VETÍTVE]}

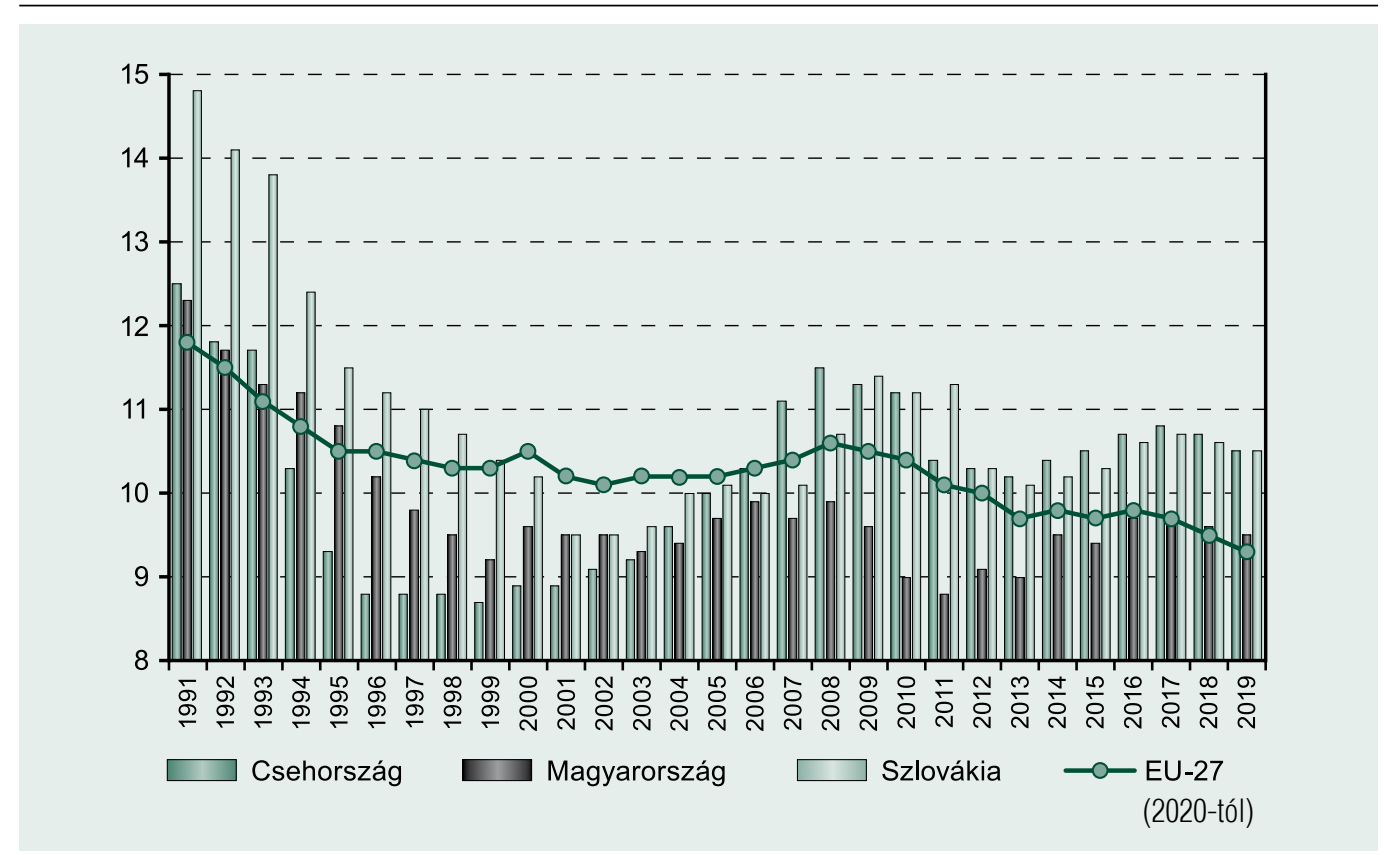

Forrás: Eurostat 
vákia népszaporulata, akárcsak a szocializmus utolsó évtizedeiben, folyamatosan meghaladja a magyarországi népszaporulatot.

A 3. ábrán látható, hogy a 2010-es évek elején egy kisebb demográfiai növekedés figyelhető meg Szlovákiában. A megjelenés időszakából következtethető, hogy az első baby boom generáció unokái, a husáki gyerekek, bekerültek a szülőképes korba.

Az utóbbi száz év alatt természetesen Szlovákiában is csökkent a népszaporulat, ellenben szinte alig fordult elő olyan időszak, amikor az ország népessége abszolút mértékben esett volna. Ilyen ritka eset volt a 2001., 2002. és a 2003. esztendő, amikor a lakosság száma 20 899, 971, illetve 141 fövel lett kevesebb. ${ }^{5}$

A rendszerváltozás egy további demográfiai mutatóban, a házasságkötések számát illetően is jelentős változást hozott. Az 1990-es évek elejéig általános társadalmi elvárás volt a fiatalok házasságkötése, az utóbbi évtizedekben azonban ez gyorsan változik. Amíg a 90es évek elején a nők 93, és a férfiak 89 százaléka legalább egy házasságot már kötött, 2001-re ezek az arányok 66, illetve 63 százalékra csökkentek. Az ezredforduló után újra emelkedés jött, és az arányok 66 és 77 százalékra módosultak. A különbségek országon belül is jelentősek. A házassági hajlandóság a Zsolnai kerületben (észak-nyugat) a legkisebb, ahol 2016-18 átlagában a férfiak esetében 0,54/1 fö volt, a nők esetébenen pedig 0,62/1 fö. Az első helyen a nyolc kerületből az észak-keleten található Eperjesi kerület volt, ahol a férfiak esetében 0,71, a nők esetében pedig 0,79-es értékkel lehet találkozni (Šprocha, 2019).

A születéshez kapcsolódó változások egyik kísérő jelensége, hogy lassul a reprodukciós fo-

4. ábra

\section{NÉPESSÉGGYARAPODÁS AZ ÖNÁLLÓ SZLOVÁKIÁBAN}

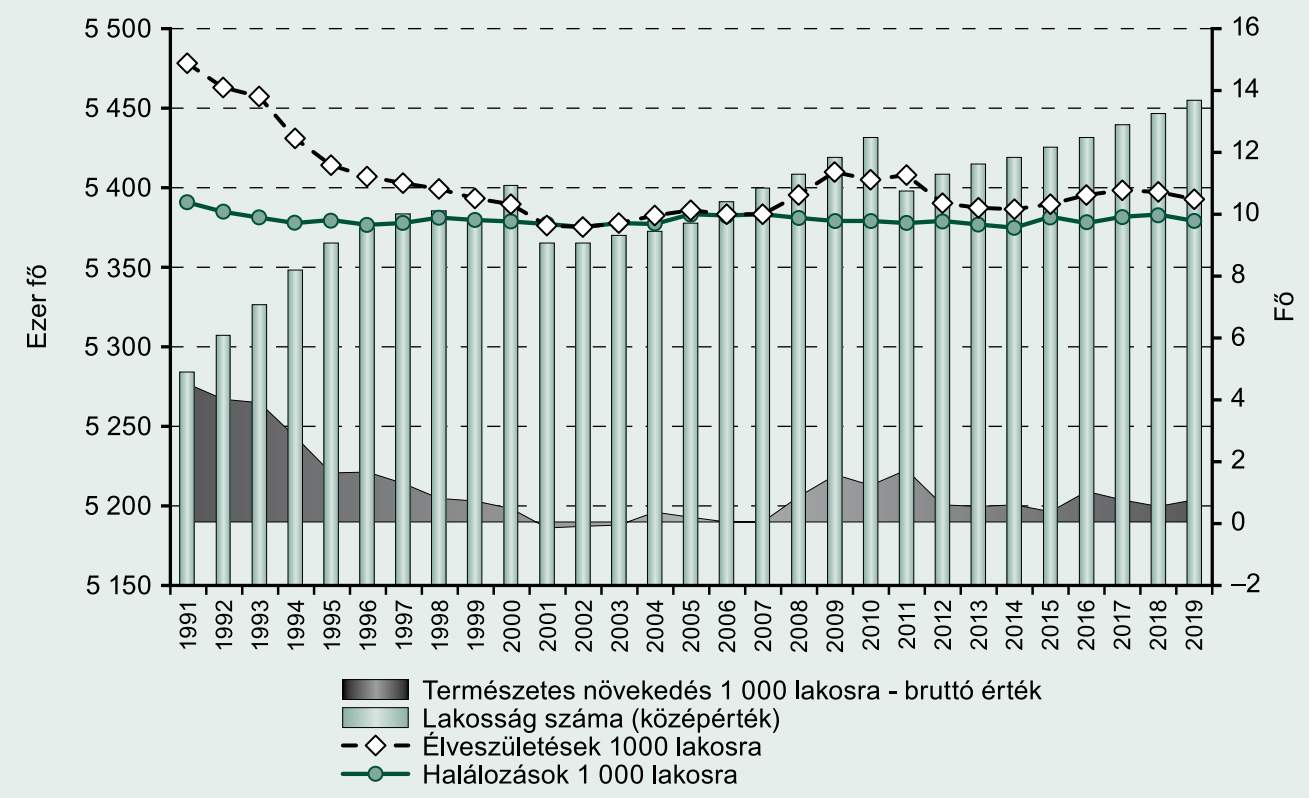

Forrás: www.statistics.sk, om2019rs_data 
lyamat, emelkedik a gyermekvállalás életkora. 1991-ben a nők első gyermeküket átlagosan 22 és fél évesen hozták a világra, 2018-ban már 27,1 évesen. Hasonló módon változott a családban és családon kívül született gyerekek aránya. A rendszerváltozás utáni 10 százalékos szintről 2018-ig már ez a szám elérte a 40 százalékot (Šprocha, 2019).

Ami a fertilitási ráta alakulását illet, hosszú távon Szlovákiába is esés tapasztalható. A 90-es évek második harmadában jelentős csökkenés ment végbe, aminek következményeként az 2 alá esett, sőt kevesebb lett, mint 1,5. A mélypont 2002-ben volt, amikor az érték 1,19 volt. Ezután lassú emelkedés indult meg, amely egy kisebb visszaesés után tovább nőtt. Az 5. ábra mutatja, hogy 2017-ben az index újra meghaladta az 1,5-ös szintet.

Mindent összegezve, Szlovákia demográfiai helyzete, összehasonlítva Kelet-Közép-Európa országaival, különösen Magyarországgal is, de számos nyugat-európai országgal, viszonylag kedvezőnek mondható. A lakosság száma enyhén növekszik és ezt migrációs többlet nélkül lehet elérni. A prognózisok azonban negatívak. Az elemzések alapján (Bleha, Šprocha, Vaňo, 2018) 2060-ra a lakosság száma a 2011ben végrehajtott legutóbbi népszámlálás idején felmért 5397036 föről a legrosszabb szcenárió szerint 4709000 fóre csökken. A legpozitívabb számítás szerint akár 5556000 före is nőhet, ellenben a legvalószínűbb az, hogy a lakosság száma 5135000 fö körül fog alakulni. 2017 és 2060 között Szlovákia lakossága több mint 308 ezer fővel, azaz 5,7 százalékkal csökkenhet, miközben a fogyás már a 2020-as évek végén megindulhat. Tekintettel arra, hogy a demográfiai probléma Szlovákiában napjaink-

\section{TELJES TERMÉKENYSÉGI RÁTA MAGYARORSZÁGON ÉS SZLOVÁKIÁBAN}

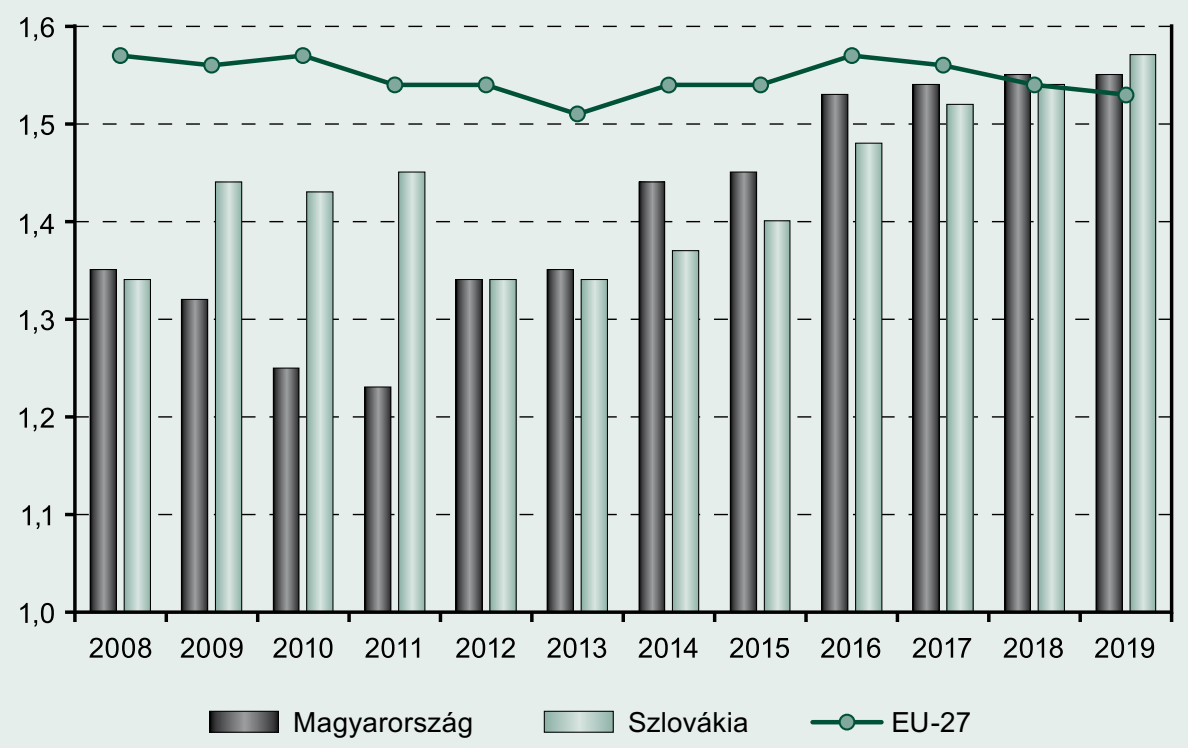

Forrás: Eurostat [tps00199] 
ban még nem egy égető kérdés, aránylag kevés figyelem hárul rá. A jelenleg stabilnak tekinthető demográfiai helyzet ellenére Szlovákiának is szembe kell nézni a modern társadalmak egyik legnagyobb kihívásával, az öregedéssel. Ez a legnegatívabban a nyugdíjrendszerre hat, de az életkor meghosszabbodása kétségtelenül egy nagyon pozitív tény.

\section{CSALÁDTÁMOGATÁS SZLOVÁKIÁBAN}

„A Szlovák Köztársaság állami családpolitikájának koncepciója, hogy a családpolitikát az általános szabályrendszerek, intézkedések és eszközök olyan rendszerének tekinti, amelyekkel az állam közvetlenül, illetve közvetetten támogatja a család kiemelten fontos jelentöségét minden egyes ember fejlödésére a társadalomban, továbbá kifejezi annak fontosságát. "(Sika, Španková, 2014, 150). A Szlovák Köztársaság Alkotmányában a családdal két rész foglalkozik. A 19. rész 2) pontjában szerepel, hogy mindenkinek joga van a magánéletre és a családi életre. A 41. rész 1) bekezdésének négy mondata közül kettő utal a családra és gyermekre: „A házasság, a gyermeknevelés és a család a törvény védelme alatt áll. A gyermekek és a fiatalkorúak különleges védelme biztositott." Majd a 4) bekezdésben a következő olvasható: „A gyermekekröl való gondoskodás és nevelésük a szülök joga; a gyermeknek joguk van a szülöi gondoskodásra és nevelésre. A szülök jogait a kiskorú gyermekre vonatkozóan akaratuk ellenére csak birói döntéssel lehet korlátozni.” Az 5) bekezdés a következőket tartalmazza: „A szülök, akik gyermekröl gondoskodnak, jogosultak az állam támogatására."

A család fogalmát a Családokról szóló $36 / 2005$ sz. törvény 1 . cikkelye így határozza meg: „A házasság férfi és nö kapcsolata”, majd a negyedik mondtat így szól: „A házasság fó célja a család létrehozása és gyermekek rendes nevelése."
A családpolitikát az államigazgatáson belül a Szlovák Köztársaság Szociális és Családügyi Minisztériuma irányítja. A családtámogatás különféle fajtáira 2020-ban összesen 995445 418,30 eurót költöttek (www.upsvar. sk). A minisztérium a 2020-as esztendő folyamán 2847720161 euróval gazdálkodhatott. Megjegyezendő, hogy például az Oktatási, Tudományi, Kutatási és Sportügyi Minisztérium költségvetése 1581963859 eurót tett ki, a Honvédelmi Minisztériumnak pedig 1608226356 euró jutott. Ez azt jelenti, hogy a szlovák Népjóléti Minisztérium a költségvetés 15,33 százalékával gazdálkodhatott, (www. finance.gov.sk) ezen belül családtámogatásra a költségvetési kiadások 5,36 százalékát fordították, ami a GDP értékének 1,09 százaléka. A gyermekvállalással kapcsolatos támogatásokat 13 jogcímen lehet igényelni. ${ }^{6}$

A családtámogatás a szociálpolitika egyik legfontosabb része, ezért a jogi háttér is kiterjedt, a tárgykörrel több törvény foglakozik. ${ }^{7}$ A gyermekvállalást Szlovákia az adórendszeren keresztül is támogatja. Erre minden gyermeket nevelő adózó jogosult. Az adóbónuszra az adózó a következő feltételek esetén jogosult (www. podpora.financnasprava.sk):

- az adózott jövedelme folyamatosan végzett tevékenységből elérte a minimálbér hatszorosát, ez az összeg 2020-ban 3480 euró volt,

- gyermeket tart el, akivel egy háztartásban él, a gyermek a saját gyermeke, a gyermeket örökbe fogadta, nevelőszülői feladatot lát el az illetékes szerv döntése alapján,

- megfelelő dokumentumokkal igazolja, hogy a gyermek látogatja az iskolát.

2020-ban az adóbónusz mértéke havonta 22,72 euró volt, 6 éves koráig pedig 45,44 euró volt.

A családokat az állam egyszeri, vagy ismételten folyósított pénzösszeggel támogatja. A szociális támogatások odaítélése a gyermek születésével és nevelésével kapcsolatos kiadások 
finanszírozására szolgálnak. Az állami támogatások folyósításakor a család jövedelme nem játszik szerepet, így annak mértékét nem vizsgálják, kivételt a póttartásdíj megítélése jelent. Az állami szociális rendszer által kifizetett öszszegek kizárólag a költségvetésből származnak és a kifizetést a törvények szabályozzák.

A szlovák kormány legújabb családtámogatási döntése, hogy egy egyszeri 200 eurós támogatást ad a 18 év alatti gyermeket nevelő családoknak. Az összegre azok a családok jogosultak, amelyeknek teljes bevétele nem éri el a 2000 eurót. Az összeget két részben utalják át 2021 nyarán, illetve az ősz folyamán. ${ }^{8}$ Vannak azonban átfogóbb tervek is a gyermekvállalási megbecsülésére. A jelenlegi szlovák kormánykoalíció a nyugdíjbiztosítás terén reformokat tervez. Az egyik ilyen az úgynevezett szülői nyugdíj intézménye. A nyugdíjbiztosításról szóló 462/2003 törvény módosításának tervezete alapján 2023. január 1-jétől bevezetnék a szülői nyugdíjat, más megfogalmazásban szülői bónuszt. Lényege, hogy az a dolgozó gyerek, akinek szülője öregségi-, rokkant- vagy szolgálati nyugdíjra lesz jogosult, szülőnkként átutalhatja számukra bruttó fizetésének 2,5\%-át. ${ }^{9}$

A családtámogatás rendszere azonban számos egyéb formát is magába foglal, amely közvetlenül, vagy akár közvetetten segíti a családok életét. Így például az alsó-, közép- és felsőfokú iskoláztatás, amennyiben az iskola állami fenntartású, ingyenes. Kivételt a felsőfokú levelezős oktatás jelent. Az oktatási lehetőségeken túlmenően többféle szociális, vagy tanulmányi ösztöndíj, dotált kollégium, étkezési és utazási (helyi és helyközi) támogatás stb. segíti a fiatalokat, illetve a családjukat. Hasonló módon szinte teljesen térítésmentes az egészségügy is. A családtámogatások összegének és arányának a változását az utóbbi évtizedben a 6 . ábra szemlélteti.

6. ábra

\section{A KÖZVETLEN CSALÁDTÁMOGATÁS ÖSSZEGE ÉS ANNAK ARÁNYA A GDP-BEN [FOLYÓ ÁRAKON]}

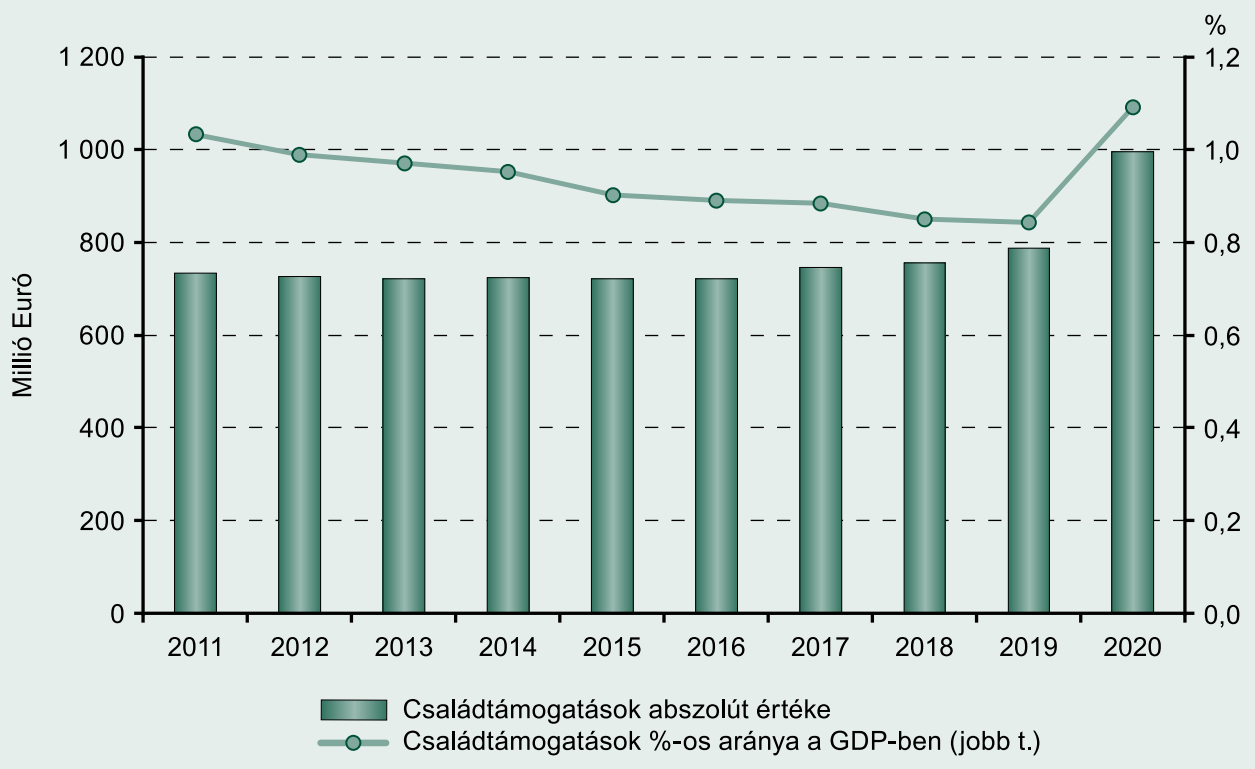

Forrás: www.upsvar.sk, GDP: www.statistics.sk, nu0007rs_data, 2020: www.mfsr.sk 
A 7. ábra néhány OECD-ország, illetve az EU és OECD egészének GDP-arányos családtámogatását mutatja. A célra 2017-ben a legtöbbet Franciaországban, a legkevesebbet Törökországban költöttek. Magyarország GDP-arányos családtámogatási mértéke közel a kétszerese, mint Szlovákiáé. ${ }^{10}$

$\mathrm{Az}$ újabb, 2019-es (de a 7. ábrában lévő OECD-módszertantól némileg eltérő Eurostat-módszertannal összeállított) Európai Unióra vonatkozó adatok alapján kijelenthető, az állami család- és gyermektámogatási kiadások Magyarországon (változatlanul) mintegy dupláját tették ki a szlovák adatoknak - 2,1 százalék versus 1,1 százalék, illetve 0,5 százalékkal haladták meg a cseh adatokat. A magyarországi számoknál csak az észak-európai országok adatai voltak jobbak. ${ }^{11}$

A családtámogatás természetesen valameny- nyi kormány deklarált prioritásai közé tartozik. A konkrét lépésekben azonban aktuálpolitikai, illetve gazdasági státuszadatok is szerepet játszanak. A 2010-es években a családtámogatásra szánt összegek mértéke nagyjából stagnált, ami a folyamatosan növekvő GDP mellett annak egyre kisebb százalékát tette ki. Ennek több oka lehet. Minden bizonnyal nagy szerepet játszott az árstabilitás, a baloldali pártkoalíció belpolitikai hatalmának biztonsága. A családok támogatása 2017-ben, majd lényegesen 2020-ban nőtt, 2016 és 2020 választási évek voltak.

A felsoroltak mellett megemlíthető, hogy az állam támogatja a fiatal családokat is, az Állami Lakásalapon keresztül. A dotált kölcsön feltétele, hogy mindkét kérelmező 35 év alatti legyen. A támogatás megszerzése nem kapcsolódik a gyermekvállaláshoz (www.sfrb.sk).

\section{GDP-ARÁNYOS BRUTTÓ CSALÁDTÁMOGATÁS 2017-BEN SZLOVÁKIÁBAN ÉS MÁS RELEVÁNS ORSZÁGBAN SZÁZALÉKBAN}

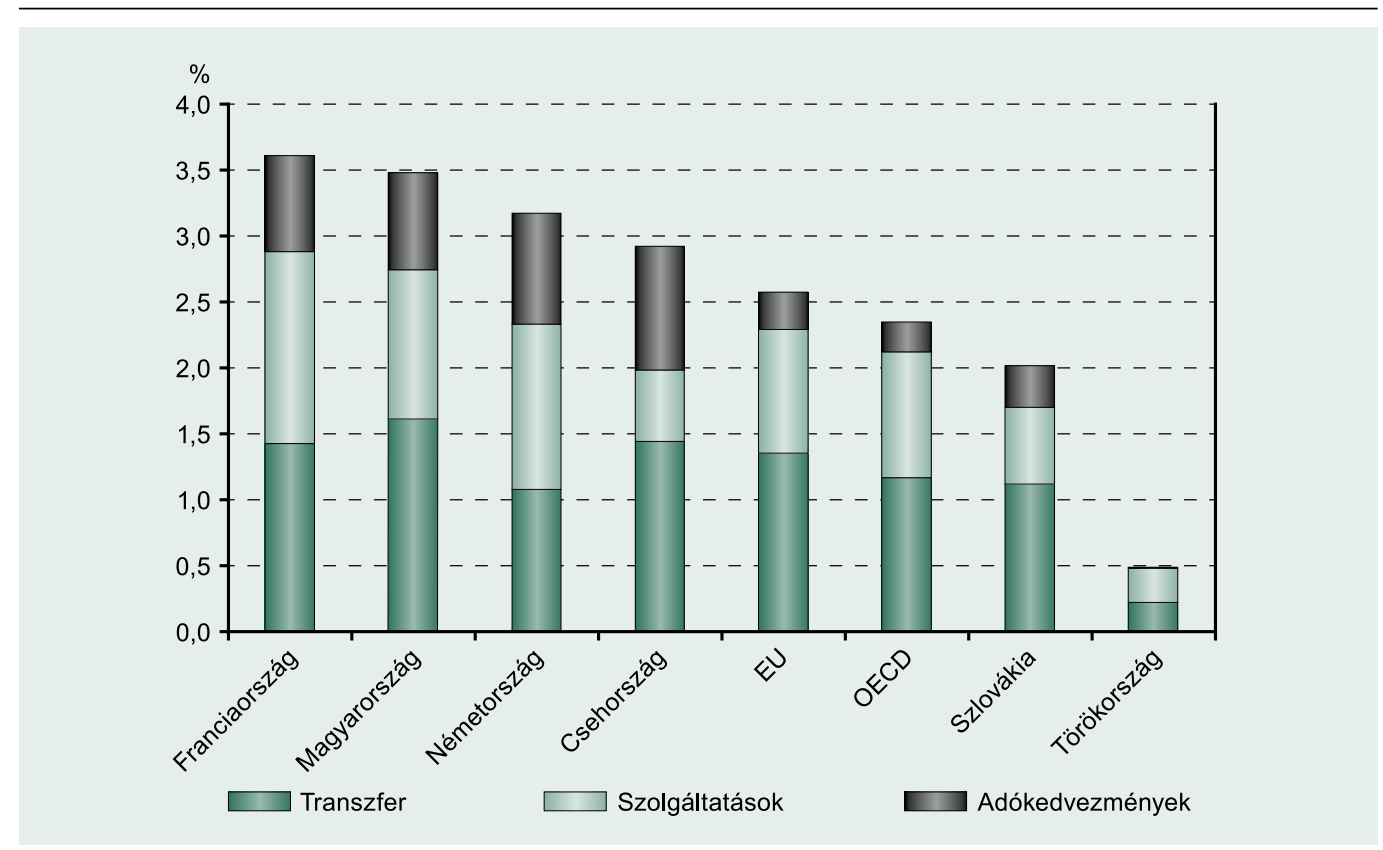

Forrás: https://www.oecd.org/els/family/database.htm 
Szlovákia jelenkori történelmében jellemzően egy markánsan jobboldali-liberális és egy baloldali kormánykoalíció váltogatja egymást, amely a szociálpolitikában is jellemzően megmutatkozott. Az utóbbi évek egyik sokat vitatott családpolitikai intézkedése volt az általános iskolai ingyenes étkezés bevezetése 2018-ban. Ezt a 2020-ban hatalomra került kormány megszüntette és bevezette az adóbónuszt.

Tekintettel arra, hogy a demográfiai folyamatok időbeli lefolyása nagyon hosszú, a szlovák szociális és családpolitikai intézkedések általában ritkán alkotnak szervezett egységet, az egyes kormányzati tervek, reformok és törvények véghezvitelét, illetve megalkotását nem egyszer akadályozzák belpolitikai események vagy gazdasági válságok. Mivel Szlovákia még „nem érzi” a lakosság számának a csökkenését, ezért a problémakör a szakpolitikában is aránylag ritkán jelenik meg, illetve hátrább kerül. Jelenleg Szlovákiában a demográfiai változásokat érintő kérdések között lényegesen nagyobb figyelem hárul a nyugdíjbiztosításra (Sika, Kovárová 2016), míg a gyermekvállalás támogatása lényegesen kevésbé tárgya a közbeszédnek. A családtámogatás alatt elsősorban a család anyagi, jóléti támogatását értik.

A demográfiai változásoknak, a gyermekvállalásnak nagyon sok társadalmi, gazdasági, szociológiai és pszichológiai tényezője volt, illetve van. Szlovákia és a szlovák nép esetében minden bizonnyal szerepet játszott, hogy az elmúlt száz év alatt több jelentős nemzettudatot, nemzeti érzést javító eseményt élt át. Egy sikeres, nemzeti céljait megvalósítani képes nép tagja jobban hisz a jövőjében is, amelyik egyik megnyilvánulása a gyermekvállalás. Szlovákia több sikerét éppen Magyarországgal, a magyar néppel szemben érte el. Ez többek között abban is megnyilvánul, hogy a vegyes házasságban született gyermekek többségi szlovák nemzetiségü lesz. Sőt, esetenként magyar szü- lők gyermekei is a szlovák nemzet népesedési mutatóit javítják. ${ }^{12}$

\section{KONKLÚZIÓ}

Kérdésfeltevésünk (Sorvachev, Yakovlev, 2019 alapján), hogy a 'támogatások legalább részben ellensúlyozzák-e a gyermekvállalással járó többletterheket (és haszonáldozatot)' és 'egy erősebb családtámogatási rendszerrel növelhető-e a gyermekvállalási hajlandóság'? A magyar kormány intenzív családtámogatási rendszere a szlovákhoz képest is kedvezőtlenebb demográfiai helyzeten kíván javítani, ám elemei számos ponton továbbfejlesztendők. A lakásépítési piacra történő állami beavatkozás még várat magára, miközben Szlovákiában hasonló, s ennyire - a magyarhoz idomuló - széleskörü támogatási formák nem léteznek.

Miáltal GDP-arányosan a magyar családtámogatási mérték a közel kétszerese, mint a gazdaságilag némileg fejlettebb Szlovákiáé, mégis úgy tűnik, hogy a kedvezőbb magyar támogatási politika átfogó pozitív hatásai még váratnak magukra. Ám ebből leszűrhető az a következtetés, hogy a gyermekvállalás mögött, az állami támogatásokon túlmenő, komplexebb társadalmi, individuális folyamatok állnak. A hagyományos létformák felbomlása, a fogyasztói társadalom, s az önmegvalósítás eszményének az egyének családépítési gyakorlatában olyan változásokat hoznak, amelyeket a születésszám alakulásában nehéz számszerüsíteni, ám a társadalmi jelenség tetten érhető, mint ahogy a csökkenő gyermekszám is. Egy-egy országban a gyermekvállalás alakulása - még ha hasonló fejlettségüek is az országok, hasonló történelmi múlttal is bírnak - mégis csak eltérő, és úgy tűnik, hogy e kultúrákban gyökerező okokat nehéz megváltoztatni, s főleg kizárólag gazdasági eszközökkel befolyásolni, vagyis többlettámogatással, több gyermek születését elérni egy adott terminus- 
ban. A magyar gyakorlatból kiindulva, ennek viszont nem mond ellent, hogy a gazdaságpolitikai ösztönzők mégis csak támogathatják a gyermekvállalási hajlandóság növekedését. Ám adódik, hogy az egyéb tényezőkre, mint például a gyermekneveléssel kapcsolatos infrastruk- túra építésére, $s$ föleg a gyermekcentrikus humánum fejlesztésére nagyobb figyelmet kell fordítani, amelyben az egyházaknak, társadalmi szervezeteknek, a nevelésnek - az állami intézkedéseken túlmenően - meghatározó szerepe lehet.

\section{JEGYZETEK}

${ }^{1}$ Legutoljára, a 2021 augusztusában bejelentett kedvezmények egyrészt a kedvezőtlenné váló családi viszonyok esetén is kompenzáló támogatást biztosítanak, másrészt pedig kamatmentes lesz a CSOK-hoz kapcsolódó kölcsöne annak, aki energiahatékony új otthont épít vagy vásárol a Magyar Nemzeti Bank programja keretében.

$2 \mathrm{Az}$ adatok forrása: https://www.ksh.hu/stadat_ files/nep/hu/nep0006.html (letöltve: 2021. 08. 16.) Sőt, az élve születések száma 2011-ben, 2013-ban, 2018-ban, 2019-ben 90 ezer alá süllyedt.

3 2011-ben történt egy alapos kutatás, amely a már akkor is kedvezőtlen magyar, szlovák és cseh születési adatokat vetette össze (Berde, Németh, 2011). A tanulmány 1970 és 2011 között háromfajta naptári éves termékenységi arányszám (a hagyományos teljes termékenységi arányszám, az ütem és paritás szerint korrigált Bongaarts-Feeney-féle, valamint Kohler-Ortega-féle teljes termékenységi ráta) segítségével bemutatta, hogy bár a két korrigált teljes termékenységi ráta értékei az 1990-es és 2000-es években mindhárom országban magasabbak voltak, mint a teljes termékenységi arányszám, még így se érték el a reprodukciós határt. A szerzők Magyarország helyzetét a legkedvezőtlenebbnek ítélték a 2011 előtti időszakban.

${ }^{4}$ Lényeges arra utalni, hogy ebben az időszakban Magyarországon is hasonló demográfiai adatok zajlottak le. Az 1000 lakosra jutó élveszületési szám 1968-tól, az Új Gazdasági Mechanizmus létrejöttétól, egészen 1980-ig, a tervgazdaság nyilvánvaló gyengüléséig folyamatosan emelkedett, 15 feletti értékkel rendelkezett. A legmagasabb ezer lakosra vetített gyermekszám 18,4 volt 1975-ben. Az 1980-as évektől 1996-ig 13,9 és 10,2 között ingadozott, majd 1997-től 10 alá csökkent, amely szinten meg is állt.

5 Magyarországon a népesedés természetes fogyása 1981-től folyamatos és növekvő mértékü. A 2010 utáni időszakban évente átlagban 40 ezer körüli.

${ }^{6}$ Az igénylés jogcímeit és az aktuális támogatás öszszegeit lásd https://www.employment.gov.sk/sk/ rodina-socialna-pomoc/podpora-rodinam-detmi/ penazna-pomocl

7 A törvények felsorolását lásd https://www. employment.gov.sk/sk/rodina-socialna-pomoc/ podpora-rodinam-detmi/penazna-pomocl

8 A bejelentés részleteiről: https://www.employment. gov.sk/sk/uvodna-stranka/informacie-media/ aktuality/rodiny-dostanu-jednorazovy-pandemickyprispevok.html (letöltés ideje: 2021. 09. 02.)

9 https://www.podnikajte.sk/pripravovane-zmenyv-legislative/novela-zakona-o-socialnom-poisteni2022-2023

${ }^{10} \mathrm{Az}$ elemzés során kerülni szándékoztuk a Covid19-járvány gyermekvállalásra, családtámogatásra 
vonatkozó hatásait, így elemzésünk a krízis előtti (auditált), jobbára 2017-es, 2019-es nemzetközi összehasonlító adatoknál „megáll”.

${ }^{11}$ Eurostat adatok forrása: https://stats.oecd.org/ index.aspx?queryid=68251 (letöltve: 2021. 09 . 02.)
${ }^{12}$ Ezen érzelmi-logikai váz mentén adódik, hogy egy nemzet gazdasági-politikai sikerei, pozitívvá váló jövőképe a gyermekvállalást előmozdító tényezők, amihez szlovák-magyar relációban (az országok, illetve a nemzetiségek között) a további eredményes kooperáció is hozzájárulhat, akár Magyarországon, akár Szlovákiában.

IRODALOM

Banyár J. (szerk.), Németh Gy. (szerk.) (2020). Nyugdij és gyermekvállalás 2.0: Nyugdijreform elképzelések. Konferenciakötet, Gondolat Kiadó

Baughman, R., Dickert-Conlin, S. (2009). The earned income tax credit and fertility. Journal of Population Economics, 22(3), pp. 537-563

Beaujouan, E., SobotKa, T., Brzozowska, Z., Zeman, K. (2017). Has childlessness peaked in Europe? Population \& Societies, 540, pp. 1-4, https://www.ined.fr/fichier/s_rubrique/26128/540. population.societies.2017.january.en.pdf

Berde É., Németh P. (2015). Csehország, Magyarország és Szlovákia termékenységi idősorainak összehasonlítása (1970-2011). Statisztikai Szemle, 93(2). 113-141. oldal

Bleha, B., Šprocha, B., VAŇo, B. (2018). Prognóza obyvatelstva Slovenska do roku 2060. [Szlovákia lakossági prognózisa 2060-ra]. Bratislava, INFOSTAT - Inštitút informatiky a štatistiky

Boтоs K. (2019). Beszámoló a Nyugdíj és gyermek 2.0 konferenciáról. Hitelintézeti Szemle, 18(3), 158-163. oldal

Dorbritz, J., Ruckdeschel, K. (2007). Kinderlosigkeit in Deutschland. Ein europäischer Sonderweg? Daten, Trends und Gründe. Konietzka,
D., Kreyenfeld (Ed.), Ein Leben ohne Kinder. Wiesbaden, VS Verlag für Sozialwissenschaften, pp. 45-81,

https://doi.org/10.1007/978-3-531-90323-1

Gajdoš, P., PAšiak, J. (2006). Regionálny rozvoj Slovenska z pohladu priestorovej sociológie. [Szlovákia regionális fejlódése a területi szociológia szempontjából]. Bratislava, Sociologický ústav SAV

GidAy A. (2012). Életciklus-szemlélet és a társadalombiztosítás bevételei. Polgári Szemle. 8(3-6), 165-181. oldal

Gyurgyík L. (1994). Magyar mérleg. Kalligram, Pozsony

Habaj, M., LukačKa, J., Segeš, V., Mrva, I., Petranskŕ, I., Hrnko, A. (2015). Slovenské dejiny od úsvitu po súčasnost.'. [Szlovákia története a kezdetektöl napjainkig.] Bratislava, Perfekt, https://ec.europa. eu/eurostat/data/database

Jašek, P., Podolec, O., Katrebová-Blehová, B., Sivoš, J. (2019). Od totality $k$ slobode. Nežná revolúcia 1989. [From a totalitarian regime to freedom. The gentle Revolution 1989.] Bratislava, Ústav pamäti národa

LešKo, M. (1998). Mečiar és a mečiarizmus. [Mečiar és mečiarizmus.] Budapest-Pozsony, BalassiKalligram 
Liefbroer, A. C. (2009). Changes in family size intentions across young adulthood: a life-course perspective. Eur J Popul, 25(4), pp. 363-386

Luci-Greulich, A., Thévenon, O. (2013). The impact of family policy packages on fertility trends in developed countries. Eur J Popul, 29(2), pp. 387416

MináLYi P. (2019). A gyermekvállalás határhasznai és határköltségei. Pénzügyi Szemle, 64(4), 554569. oldal, https://doi.org/10.35551/PSZ_2019_4_5

Mikıoš, I. et al. (2005). Kniha reforiem. [Reformok könyve.] Bratislava, Trend Visual

NAGY L. (2016). Munkanélküliség versus foglalkoztatottság. Polgári Szemle, 12 (4-6), 237-248. oldal

Neyer, G. (2006). Family policies and fertility in Europe: fertility policies at the intersection of gender policies, employment policies and care policies. MPIDR Working Papers WP-2006-010, Max Planck Institute for Demographic Research,

https://doi.org/10.4054/MPIDR-WP-2006-010

Neyer, G., Thévenon, O., Monfardini, C. (2016). Policies for Families: Is there a Best Practice? Families and Societies. European Policy Brief, pp. 1-12, https://population-europe.eu/sites/default/ files/policy_brief_final.pdf

NovÁK K. (2020). „A magyar családpolitikának kettős célja van”. Online https://csalad.hu/ tamogatasok/a-magyar-csaladpolitikanak-kettoscelja-van.

Prưcha, V. et al. (2009). Hospodárské a sociální dèjiny Čskoslovenska. 2. díl obdobi 1945-1992. [Csehszlovákia gazdaság- és társadalomtörténete. 2. rész. 1945-1992.] Brno, Doplněk
Riederer, B., Buber-Ennser, I. (2016). Realisation of Fertility Intentions in Austria and Hungary: Are Capitals Different? Vienna Institute of Demography Working Papers, No. 08., online: https:// www.oeaw.ac.at/fileadmin/subsites/Institute/VID/ PDF/Publications/Working_Papers/WP2016_ 08.pdf.

SÁgi, J., Lentner, Cs. (2018). Certain Aspects of Family Policy Incentives for Childbearing - A Hungarian Study with an International Outlook. Sustainability, 10(11), pp. 39-76, https://doi.org/10.3390/su10113976

Sági, J., Tatay, T., Lentner, Cs., Neumanné VIráG, I. (2017). Certain Effects of Family and Home Setup Tax Benefits and Subsidies. Pénzügyi Szemle/Public Finance Quarterly, 62(2), pp 171-187

SiKa, P., Kovárová M. A. (2016). Sustainability of the Pension System of the Slovak Republic in the Changed Socio-Economic Conditions. Journal of Security and Sustainability. 6(1), pp. 113123

Sika, P., Španková, J. (2014). Sociálne zabezpečenie. [Társadalombiztositás.] Trenčín, Trenčianska Univerzita Alexandra Dubčeka v Trenčíne, Fakulta sociálno-ekonomických vztahov

Singhammer J. (2019). A family gives you a home and boosts the abilities of children. Budapesti Demográfiai Csúcs, Online, https://csalad.hu/ tamogatasok/johannes-singhammer-a-familygives-you-a-home-and-boosts-the-abilities-ofchildren

Soвотка, T. (2011). Fertility in Central and Eastern Europe after 1989: Collapse and gradual recovery. Historical Social Research, 36(2), pp. 246296

Sorvachev, I., Yakovlev, E. (2019). Short-Run and Long-Run Effects of Sizable Child Subsidy: 
Evidence from Russia. NES Working Paper, 254. LSE IGA Research Working Paper Series, 8

Šprocha, B., (szerk.), Bleha, B., Garajová, A., Pilinská, V., Mészáros, J., Vaño, B. (2019). Populačný vývoj $v$ krajoch a okresoch Slovenska od začiatku 21. storočia [A lakosságszám növekedése Szlovákia kerületeiben és járásaiban a 21. század elején.] INFOSTAT - Výskumné demografické centrum, Univerzita Komenského, Prírodovedecká fakulta, Centrum spoločenských a psychologických vied SAV, Prognostický ústav SAV

Stefán-Makay, Zs. (2009). A franciaországi családpolitika és a magas termékenység összefüggése. Demográfia, 52(4), 313-348. oldal

Tatay T., Sági J., Lentner Cs. (2019). A családi otthonteremtési kedvezmény költségvetési terheinek elöreszámítása, 2020-2040. Statisztikai Szemle, 97(2), 192-212. oldal, https://doi.org/10.20311/stat2019.2.hu192

Whittington, L. A. (1992). Taxes and the family: the impact of the tax exemption for dependents on marital fertility. Demography 29(2), pp. 215-226
Zemкo, M., BystrickÝ, V. (2004). Slovensko v Československu 1918-1939. [Szlovákia Csehszlovákiában 1918 és 1939 között.] Bratislava, Vydavatel'stvo Veda

Munkaügyi, Szociális és Családügyi Hivatal, www.upsvar.sk

Munkaügyi, Szociális és Családügyi Minisztériuma, www.employment.gov.sk

Štatistická ročenka Slovenskej republiky 1995. [Szlovákia statisztikai évkönyve 1995.]. Bratislava, Slovenský štatistický úrad, Veda

Štatistická ročenka Slovenskej republiky 2017. [Szlovákia statisztikai évkönyve 2017.]. Slovenský štatistický úrad, Veda, Bratislava

Szlovák Statisztikai Hivatal, www.statistics.sk

Szlovákia Pénzügyminisztériuma, www.mfsr.sk, www.finance.gov.sk

Szlovákia Pénzügyőrsége, www.financnasprava.sk 